\title{
Impact of Goal Setting and Training on Job and Firm Performance in Pakistan
}

\author{
Syed Haider Jaffery ${ }^{1}$, Hina Affandi ${ }^{2}$ \\ ${ }^{1,2}$ (Department of Management \& Economics, Foundation University Rawalpindi Campus, Pakistan)
}

\begin{abstract}
The aim of the present paper is to examine a framework in which goal setting that is HR input and training that is HR practice are theorize to cause remarkably and positively to job and firm performance. We concluded that positive impact of goal setting on job performance is partially mediated by training and positive impact of goal setting on firm performance is significantly mediated by training. The sample size for this research is 101 managerial level employees of business firms that are located in twin cities Rawalpindi and Islamabad of Pakistan.
\end{abstract}

Keywords: Firm Performance, Goal Setting, Human Resource Management System, Job Performance, Training

\section{Introduction}

Organizations decrease their capability to contest equally nationwide as well as globally without high standard training and properly groomed work force that effect in decline in economic sustainability (i.e., [1]). The structural model having goal setting as predecessor to training, training as predecessor to job performance and firm performance is hypothesize and evaluated in this research.

Figures come through convenience sampling of 101 managers are examined. This research factually analyzes that does the positive impact of goal setting on job performance is positively mediated by training and does the positive impact of goal setting on firm performance is positively mediated by training. The research gap was found from study of (i.e., [2]). According to researchers later investigation could be performed to investigate goal setting as HR input that affect performance of employees and organizations (i.e., [2]). So in our research we have made goal setting that is HR input as an independent variable. The analysis of the studies upon goal setting proposed that it had been basically observed as motivational approach, in conformity with the style practiced by (i.e., [3]). In our research framework we have made Training as a mediating variable that is part of HR process. As we have added single HR process as mediating variable that is training it is also proved by researchers. According to research, in aggregate organization performance and organization output could positively affect by only one human resource practice from all HR practices which is recommended by majority of researches (i.e., [2]). Researchers also proved (model) theoretically that performance is favorably influenced when employees are trained on goal setting (i.e., [4]).

Researcher hypothetical design of SCA (i.e., [5]) and researcher RBV of organization (i.e., [6])act like the hypothetical structure of our present research. Researcher proposed that competitive edge happens after organizationbecomes capable towards transferring similar advantages like rivals on less price and provide advantages that are better than organization rivals (i.e., [5]). Organization competitive edge exist upon activities performed towards establishing the secure place in market and create better earnings upon financing then finally build superior quality (i.e., [2]). Researcher concentrate upon material cause of competitive edge for example less price as well as difference among commodities and utilities (i.e., [5]).Researcher (i.e., [6])construct ahead Porter's SCA research towards constructing the idea to expand that employees as well as processes include worth as well as singularity to a firm hence its likely cause of competitive edge.

Human Resource Management is defined as "HRM refers to the policies, practices and systems that influence employees' behavior, attitudes and performance (i.e., [7]). Human resource practices include determining human resource needs, recruiting, screening, training, rewarding, appraising and also attending to labor relations, health and safety and fairness concerns" (i.e., [7, 8]). Individual job performance is explained as "behaviors or actions that are relevant to the goals of the organization" (i.e., [9]). This suggested framework was also based on (i.e., [6])RB view of the organization and this is collection of variables that employees take to their organizations such as (skills and motivation)(i.e., [10])and the firm's HR practices (i.e., [11, 12])used to make and supply/deliver commodities or services that guide eventually to continuous competitive edge. In the next section we will discuss literature review and methodology. 


\section{Literature Review}

We hypothesize a structural model integrating goal setting as predecessor to training, training as predecessor to job performance and firm performance. HR inputs includes skills and motivation (in our research context goal setting that is intrinsic motivation) of workforce this facilitate the organizations HRM practices to produce and supply commodities and services which could appraised and appreciated by buyers and consumers (i.e., $[13,14])$.

\subsection{Goal Setting}

Goal setting has been defined as "process of developing and formalizing targets or objectives that an employee is responsible for accomplishing" (i.e., [15]). Several authors(i.e., [3, 16, 17, 18, 19, 20, 21, 22]) have elaborated if inside organizations there is successful goal setting it will result in positive performance from employees. Goal setting is highlighted by numerous management systems and processes some of which are MBO, TQM and constant development measures as serious constituent for successfulness(i.e., [23, 24, 25, 26, 27]). Goal setting is investigated in two ways, first one is motivational effect in direction of enhancing performance (i.e., [3, 16, 28, 18, 19, 20, 21, 22])and second one is essential components of management systems intended to enhance performance (i.e., [23, 24, 25, 26, 27]). Satisfaction is favorably influenced by goal setting (i.e., [29, 30]). Performance is favorably influenced by goal setting (i.e., [29, 31]). Performance is favorably influenced by goal setting but not for all jobs and duties (i.e., [32]). Absence of employees from the workplace is decreased when employees are trained on goal setting (i.e., [4]). Performance is favorably influenced when employees are trained on goal setting (i.e., [4]).Performance and satisfaction is favorably influenced by goal setting (i.e., [33]). Goal setting is favorably associated with junior staff up gradation (i.e., [34]). Involvement in goal setting is favorably associated with performance for less wanted accomplishment employees (i.e., [35]).

\subsection{Training}

Training has been defined as "training is a learning experience in that it seeks a relatively permanent change in an individual that will improve the ability to perform on the job, we typically say training can involve the changing of skills, knowledge, attitudes, or behavior, it may mean changing what employees know, how they work, their attitudes towards work, or their interaction with their co-workers or supervisor" (i.e., [36]). HR practices (in our research context training) serve as a tool to transfer human resources available to a firm into better performance (i.e., [14]). The overall observations in this research judge that the organizations heads having excellent performance are strongly involved in training practices and those heads do not handover that task to someone else (i.e., [37]). Research shows that outcome directed head of organizations perceived that accurate training and coaching your employees improve the chance attaining superiorperformance and badly trained employees could generate numerous performance difficulties (i.e., [1]). In aggregate the majority of the studies recommend that only one human resource practice from (selection and recruitment, promotion and reward process, employee training, employee development, employee performance and review process) could have favorable affect upon organization output and firm performance (i.e., [2]). Researcher(i.e., [38])investigated that the existence of traditional training schemes for management, employees who belongs to union and employees who don't belongs to union, skilled and qualified employees, has an optimistic relationship with increase in employees' performance. Studies have proved that the training programs and workforce contribution schemes have optimistic effect upon organizational performance (i.e., [2]). In aggregate organization performance and organization output could positively affected by only one human resource practices from all which includes selection and recruiting processes, promotion and reward processes, employee training, development programs, employee performance and review processes (in our research context training) which is recommended by majority of researches (i.e., [2]). Research has proved a positive association among workers' involvement in training schemes, amount of output and standard of output (i.e., [39]). Studies had proved that the organizational performance is positively affected by training programs and workforce involvement schemes (i.e., [2]). Research shows that expansion in workers training timings linked to permanent decrease in waste amount in Michigan production organization (i.e., [40]). In that hurry to improve performance numerous organizations heads and their firms regularly have a view of the competitive edge to be attained by suitable training and coaching/teaching their employees that they require to contend in international economy (i.e., [41]). Research shows that according to the opinion of training experts the head of firms they found effective outcome in future approximately every time formulate training an absolute preference for their employees since they understand the results of not carrying out so (i.e., [37]).

\subsection{Job Performance}

Job Performance has been defined as "the value an organization can expect from discrete behaviors performed by employees over time" (i.e., [42]). It is also defined as "behaviors or actions that are relevant to the 
goals of the organization"(i.e., [9]). Job performance could be measured from different aspects which are defined below.

Task performance has been defined as "the proficiency with which individuals perform the core substantive or technical tasks central to his or her job" (i.e., [9]). Contextual performance has been explained as "behaviors that support the organizational, social, and psychological environment in which the technical core must function"(i.e., [43]). CWB could explained like "counterproductive work behavior is behavior that harms the wellbeing of the organization (i.e., [44]). Adaptive Performance has been explained as "the extent to which an individual adapts to changes in the work role or environment (i.e., [45]). Performance is favorably influenced by goal setting (i.e., [29]). Job performance is general field of concern for investigators, managers and owners of business firms and couldexist as key significant concept in HRM researches (i.e., [46]). Researcher looks goal setting like an approach used to improve workforce's successive performance (i.e., [3]).

\subsection{Firm Performance}

Competitive edge is critically caused by successful execution of human resource management processes in the firms and has been presented to take a positive association with firm performance (i.e., [47, 48, $49,50]$ ). Performance is favorably influenced by goal setting (i.e., [29]). Numerous researchershad proved that HRM process both independently as well as system are linked to excellent firm performance (i.e., [51, 52, 53]). Studies had proved that the organizational performance is positively affected by training programs and workforce involvement schemes (i.e., [2]). Similar by the structure opinion of Human Resource Management, the performance of the firm act like the last result of the successful human resource process (i.e., [14]).Financial figures and market values represents wide criterion of firm monetary performance. Although above mentioned better aimed monetary steps of firm performance might look excellent aimed at calculating performance of the firm (i.e., [2]). Researcher shows for the significant relationship frequently establish among aimed and intuitive actions of performance so intuitive actions have suitable mainly for investigative studies, Since numerous authors choose since intuitive measures of firm performance like buyer fulfillment and worth of firm in market (i.e., [54]).

\section{Methodology}

In this present research we practiced convenience sampling technique. The sample size for this research is 101 managerial level employees of business firms that are located in twin cities Rawalpindi and Islamabad of Pakistan. Researchers circulated 150 questionnaires and get back 101 questionnaires, response rate is 67.3 percent. The questionnaire that we have designed consists of 47 items. The 6 items of organization back ground variables are adopted from (i.e., [2]). The 4 items of goal setting in our research are adopted and designed from (i.e., [55])(for example "Effective goal setting is taught?"). The 3 items of job performance in our research are designed and adopted from (i.e., [55])(for example "My individual goals directly support the goals of the organization?") and 11 items of job performance are designed by (i.e., [56]) and adopted by (i.e., [2])(for example "Use of problem skills?"). The 7 item of firm performance in our research are adopted from (i.e., [13])(for example "How would you compare your organization's quality of products, services or programs?"). The 4 items of training in our research are designed and adopted from (i.e., [57])(for example "Training is included in firm development projects and helps the firm identify their skill needs?") and ten items are adopted from (i.e., [37]) ("Is employee training a top priority for our leaders?") and 1 item is adopted from (i.e., [2]). Complete items of questionnaire are measured on five-point Likert scale.

Table 1: Reliability Coefficients for Major Variables

\begin{tabular}{|c|c|c|}
\hline Variable & Number of items & Cronbach's Alpha \\
\hline Goal Setting & 4 & 0.839 \\
\hline Job Performance & 14 & 0.856 \\
\hline Firm Performance & 8 & 0.784 \\
\hline Training & 15 & 0.872 \\
\hline
\end{tabular}

N=101, Goal Setting (Independent Variable), Training (Mediating Variable), Job Performance (Dependent Variable), FP=Firm Performance (Dependent Variable).

The reliability of the measures were assessed through Cronbach's Alpha coefficients. The Cronbach's Alpha for each measure are shown in the Table 2 and range from 0.784 to 0.872 . 


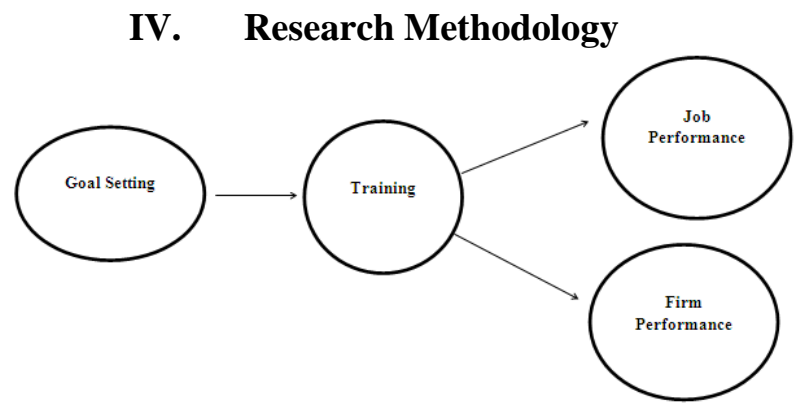

\section{Hypotheses}

H1: The positive impact of Goal setting on Job performance is significantly mediated by Training.

H2: The positive impact of Goal setting on Firm performance is significantly mediated by Training.

\section{Data Analysis}

Table 2: Profiles of Respondents

\begin{tabular}{|c|c|c|}
\hline Variables & Frequency & Percentage \\
\hline \multicolumn{3}{|l|}{ Gender } \\
\hline Male & 74 & 73.3 \\
\hline Female & 27 & 26.7 \\
\hline \multicolumn{3}{|l|}{ Age } \\
\hline Between 20-30 & 57 & 56.4 \\
\hline Between 31-40 & 29 & 28.7 \\
\hline Between 41-50 & 9 & 8.9 \\
\hline Above 50 & 6 & 5.9 \\
\hline \multicolumn{3}{|l|}{ Qualification } \\
\hline Graduation & 37 & 36.6 \\
\hline Masters & 56 & 55.4 \\
\hline Others & 8 & 7.9 \\
\hline \multicolumn{3}{|l|}{ Income } \\
\hline Above 20000 & 41 & 40.6 \\
\hline Above 30000 & 21 & 20.8 \\
\hline Above 40000 & 17 & 16.8 \\
\hline Above 50000 & 22 & 21.8 \\
\hline \multicolumn{3}{|l|}{ Experience } \\
\hline 0-1 Year & 41 & 40.59 \\
\hline 1-2 Years & 22 & 21.78 \\
\hline Above 5 Years & 38 & 37.62 \\
\hline \multicolumn{3}{|l|}{ Job Function } \\
\hline Human Resource Management & 43 & 42.57 \\
\hline Management & 34 & 33.66 \\
\hline Others & 24 & 23.76 \\
\hline
\end{tabular}

\section{$\mathrm{N}=101$}

Table 1 shows almost 72.3 percent of the participants are men and remaining 26.7 percent are women. Qualification of almost 37 percent of the participants is graduation, qualification of 55 percent of participants is masters and outstanding 7 percent of the participants marked their qualification as other. Investigation of the others outcome disclose that these qualifications mainly contain MS and DBA. The age of 56.4 percent participants exist between 20-30, other 28.7 percent participants exist between 31-40, other 8.9 percent participants exist between $41-50$ and remaining 5.9 percent participants age is more than 50 years. The income of 40.6 percent employees exist between 20000-30000, income of other 20.8 percent participants exist between $30000-40000$, income of other 16.8 percent participants exists between $40000-50000$ and income of remaining 21.8 percent is above 50000. The experience of 40.59 percentage participants exists between $0-1$ years, 21.78 percent participants exists between 1-2 years, 37.62 percent above 5 years. The job area of 42.57 percent participants is human resource management, 33.66 percent participants is management and remaining 23.76 percent of the participants marked their job area as others. Investigation of the others outcome disclose that these job areas mainly contain administration and marketing. 
Table 3: Descriptive Statistics for Variables

\begin{tabular}{lcccc}
\hline Variable & Minimum & Maximum & Mean & SD \\
\hline Goal Setting & & & & \\
Job Performance & 3.25 & 16.25 & 11.9678 & 2.91455 \\
Firm Performance & 22.21 & 60.21 & 50.8373 & 6.70028 \\
Training & 16.50 & 34.63 & 27.9282 & 3.79083 \\
\hline
\end{tabular}

N=101, Goal Setting (Independent Variable), Training (Mediating Variable), Job Performance (Dependent Variable).

The mean of Goal Setting is 11.9678 and SD is 2.91455 ranged 22.21-60.21, mean of Job Performance is 50.8373 and SD is 6.70028 ranged 22.21-60.21, mean of Firm Performance is 27.9282 and SD is 3.79083 ranged 16.50-34.63, mean of Training is 51.9855 and SD is 7.33197 ranged 23.07-65.33.

Table 4: Correlation Matrix

\begin{tabular}{lllll}
\hline Variables & GS & TRA & JP & FP \\
\hline & & & & \\
Goal Setting & 1 & & & \\
Training & $0.433^{* *}$ & 1 & & \\
Job Performance & $0.417^{* *}$ & $0.520^{* *}$ & 1 & \\
Firm Performance & $0.393^{* *}$ & $0.631^{* *}$ & $0.558^{* *}$ & 1 \\
\hline
\end{tabular}

$\mathbf{N}=101, * *$ Correlation is significant at the 0.01 level (two tailed)

GS=Goal Setting (Independent Variable), TRA=Training (Mediating Variable), JP=Job Performance (Dependent Variable), FP= Firm Performance (Dependent Variable).

Goal setting has positive relation with training with correlation coefficient of 0.433 significant at 0.01 . Goal setting has positive relation with job performance with correlation coefficient of 0.417 significant at 0.01 level. Goal setting has positive relation with firm performance with correlation coefficient of 0.393 significant at 0.01 level. Training has positive relation with job performance with correlation coefficient of 0.520 significant at 0.01 . Training has positive relation with firm performance with correlation coefficient of 0.631 significant at 0.01 .

Table 5: Regression Analysis (Hypothesis 1)

\begin{tabular}{|c|c|c|c|c|c|c|}
\hline \multirow[b]{2}{*}{$\begin{array}{l}\text { Predictor Variable } \\
\text { Goal Setting }\end{array}$} & \multicolumn{3}{|c|}{ Training } & \multicolumn{3}{|c|}{ Job Performance } \\
\hline & $\begin{array}{c}\mathbf{B} \\
0.262 *\end{array}$ & $\begin{array}{c}\mathbf{R}^{\mathbf{2}} \\
0.327^{*}\end{array}$ & $\begin{array}{r}\Delta \mathbf{R}^{2} \\
0.057^{*}\end{array}$ & $\mathbf{B}$ & $\mathbf{R}^{2}$ & $\Delta \mathbf{R}^{2}$ \\
\hline Goal Setting & & & & $0.236^{*}$ & $0.174^{*}$ & $0.174^{*}$ \\
\hline Training & & & & $0.417 *$ & $0.318 *$ & $0.142 *$ \\
\hline
\end{tabular}

\author{
Mediation \\ Goal Setting $\quad 0.236^{*} \quad 0.315^{*} \quad 0.045^{*}$
}

N=101, Goal Setting (Independent Variable), Training (Mediating Variable), Job Performance (Dependent Variable).

Table that is mentioned above presents the regression analysis for first hypothesis. Goal setting has significant impact upon training as the beta is $0.262 *, R^{2}$ is $0.327^{*}$ and $\triangle R^{2}$ is $0.057 *$. Training has significant impact upon job performance as the beta is $0.417^{*}, R^{2}$ is $0.318^{*}$ and $\triangle R^{2}$ is $0.142^{*}$. Goal setting has significant impact upon job performance as the beta is $0.236^{*}, \mathrm{R}^{2}$ is $0.174^{*}$ and $\triangle \mathrm{R}^{2}$ is $0.174^{*}$.

Table 6: Regression Analysis (Hypothesis 2)

\begin{tabular}{lcccccc}
\hline & \multicolumn{3}{c}{ Training } & \multicolumn{3}{c}{ Firm Performance } \\
\hline Predictor Variable & $\mathbf{B}$ & $\mathbf{R}^{\mathbf{2}}$ & $\triangle \mathbf{R}^{2}$ & $\mathbf{B}$ & $\mathbf{R}^{\mathbf{2}}$ & \multicolumn{1}{c}{$\Delta \mathbf{R}^{\mathbf{2}}$} \\
Goal Setting & $0.219^{*}$ & $0.439^{*}$ & $0.041^{*}$ & & & \\
Goal Setting & & & & $0.147^{*}$ & $0.154^{*}$ & $0.154^{*}$ \\
$\begin{array}{l}\text { Training } \\
\text { diation }\end{array}$ & & & $0.568^{*}$ & $0.416^{*}$ & $0.262^{*}$ \\
Goal Setting & & & & & \\
\end{tabular}

N=101, Goal Setting (Independent Variable), Training (Mediating Variable), Firm Performance (Dependent Variable). 
Table that is mentioned above presents the regression analysis for second hypothesis .Goal setting has significant impact upon training as the beta is $0.219^{*}, R^{2}$ is $0.439^{*}$ and $\triangle R^{2}$ is $0.041^{*}$. Training has significant impact upon firm performance as the beta is $0.568^{*}, R^{2}$ is $0.416^{*}$ and $\triangle R^{2}$ is $0.262^{*}$. Goal setting has significant impact upon firm performance as the beta is $0.147^{*}, R^{2}$ is $0.154^{*}$ and $\triangle R^{2}$ is $0.154^{*}$.

\section{Conclusion}

Although researchers concluded that goal of this present research has effectively achieved. In this present research researchers analyze does the positive impact of goal setting on job performance is significantly mediated by training? And does the positive impact of goal setting on firm performance is significantlymediated by training? From the analysis of 101 Pakistani managers we concluded that positive impact of goal setting on job performance is partially mediated by training (it means there are other many factors that enhances job performance) and positive impact of goal setting on firm performance is significantly mediated by training but not too much strongly which means there are also some other factors such as macro-economic factors, better law \& order conditions that enhances firm performance. So to gain competitive that is main objective of the organizations, so firm employees are trained upon goal setting to improve job and firm performance and eventually gains competitive advantage.

\section{Limitations and Future Recommendations}

This study is restricted to the analysis of Pakistan's business firms' representatives' belief of human resource inputs, human resource processes and performance variables. It is likely that the generalizability of the findings would have restricted by sampling technique yet the firms' members show a huge variety of firms' types as in earlier firm study (i.e., [12]). The generalizability of the above mentioned results could have been improved by huge sample size (i.e., [58]). In extension it could be beneficial in assessing in later studies not alone goal setting just as we have in this present research but other inputs such as curiosity, risk taking and creativity this could have more effective and as well as better constant results upon job performance and organization performance.

\section{Journal Papers:}

\section{References}

[1]. Tomaka, L.A. (2001). Workforce development in the Midwestern region.Spectrum, 74: 26-7.

[2]. Ferguson, K.L., \&Reio, T.G. (2010). Human resource management systems and firm performance.Journal of Management Development, 29(5): 471-494

[3]. Locke, E. (1968). Toward a theory of task motivation and incentives.Organizational Behavior and Human Performance, 3(2): 157189.

[4]. Latam, G.P. and S.B. Kinne. (1974). Improving Job Performance through Training in Goal Setting, Journal of Applied Psychology, 59:187-91.

[5]. Porter, M.E. (1985), Competitive Advantage: Creating and Sustaining Superior Performance, Free Press, London.

[6]. Barney, J.B. (1991), Firm resources and sustained competitive advantage, Journal ofManagement, 17:99-120.

[7]. De Cieri, H., Kramar, R., Noe, R.A., Hollenbeck, J., Gerhart, B. and Wright, P. (2008), Human Resource Management in Australia.Strategy/ People/ Performance, 3rd ed., McGraw-Hill Irwin, Sydney.

[8]. Dessler, G. (2007), Human Resource Management, 11th ed., Prentice-Hall, Englewood Cliffs, NJ.

[9]. Campbell, J.P. (1990), Modeling the performance prediction problem in industrial and organizational psychology, in Dunnette, M.D. and Hough, L.M. (Eds), Handbook of Industrialand Organizational Psychology, Consulting Psychologists Press, Palo Alto, CA, 687-732.

[10]. Askov, E.N. (2000), Workplace literacy: evaluation of three model programs, Adult BasicEducation, 10:100-8.

[11]. Huselid, M.A. (1995), The impact of human resource management practices on turnover, productivity, and corporate financial performance, Academy of Management Journal, 38:635-672.

[12]. Den Hartog, D.N. \&Verburg, R.M. (2004), High performance work systems, organizational culture and the firm performance, Human Resource Management Journal, 14:55-78.

[13]. Delaney, J.T. \&Huselid, M.A. (1996), Modes of theorizing in human resource management: tests of universalistic, contingency, and configurational performance predictions, Academy of Management Journal,39:802-35.

[14]. Lado, A.A. \& Wilson, M.C. (1994), Human resource systems and sustained competitive advantage: a competency based perspective, Academy of Management, 19:699-728.

[15]. Umstot. D.D., Mitchell. T.R. \& Bell. H.C. (1978), Goal setting and job enrichment: An integrated approach to job design, Academy of Management Review, 3(4):867-879.

[16]. Latham, G.P. \&Yukl, G.A. (1975), A review of research on the application of goal setting in organizations, Academy of Management Journal, 60(4):187-191.

[17]. Matsui, T., Kakuyam, T., \&Onglatco, M.L. (1987), Effects of goals and feedback on performance in groups, Journal of Applied Psychology, 72(3): 407-415.

[18]. Tubbs, M.E. (1986), Goal setting: a meta-analytic examination of the empirical evidence, Journal of Applied Psychology, 78(1):8697

[19]. Tubbs, M.E. (1993), Commitment as a moderator of goal-relation: a case for clearer construct definition, Journal of Applied Psychology, 78(1):86-97.

[20]. Knight,D., Durham, C.C. \& Locke, E. (2001), The relationship of team goals, incentives, and efficacy to strategic risk, tactical implementation, and performance, Academy of Management Journal, 44(2):326-338.

[21]. Dweck, C.S., Hong, Y. \& Chiu, C. (1993), Implicit theories: individual differences in the likelihood and meaning of dispositional inference, Personality and Social Psychology Bulletin, 19(5):644-56. 
[22]. Sujan, H., Weitz, B.A. \& Kumar, N. (1994), Learning orientation, working smart, and effective selling, Journal of Marketing, 58(3):39-52

[23]. Zbaracki, M. (1998), The rhetoric and reality of total quality management, Administrative Science Quarterly, 43(3):602-36.

[24]. Odiorne, G. (1978), MBO: a backward glance, Business Horizons, 21(5):14-24.

[25]. Muczyk, J.P. \&Reimann, B.C. (1989), MBO as a complement to effective leadership, The Academy of Management Executive, 3:131-138.

[26]. Ivancevich, J., McMahon, T., Streidl, W. \&Szilagyi, A. (1978), Goal setting: the Tenneco approach to personnel development and management effectiveness, Organizational Dynamics, 6(3):48-80.

[27]. Walton, M. (1986), The Deming Management Method, Pedigree, New York, NY

[28]. Matsui, T., Kakuyama, T. \&Onglato, M.L. (1987), Effects of goals and feedback on performance in groups, Journal of Applied Psychology, 72(3):407-415.

[29]. Kim, J.S., \&W.C.Hamner. (1976), Effect of Performance Feedback and Goal Settings on Productivity and Satisfaction in an Organizational Setting, Journal of Applied Psychology,61:48-57.

[30]. Umstot, D.D., C.H. Bell, \&T.R.Mitchell. (1976), Effects of Job Enrichment and Task Goals on Satisfaction and Productivity: Implications for Job Design, Journal of Applied Psychology, 61:379-94.

[31]. Ivancevich, J.M. (1977), A Field Study of Different Goals Setting Treatments and Their Effects on Performance and Job Satisfaction, Academy of Management Journal, 20:406-419.

[32]. Frost, P.J., \& Mahoney. T.A. (1976). Goal Setting and the task process: An interactive influence on individual performance. Organizational Behavior and Human Performance, 17: 328-350.

[33]. Ivancevich, J.M. (1976), Effects of Goal Setting on Performance and Satisfaction, Journal ofApplied Psychology, 61:605-12.

[34]. Mendleson, J.L. Manager Goal Setting: An Exploration into Its Meaning and Measurement (D.B.A. dissertation, Michigan State University, 1967)

[35]. Steers, R.M. (1975), Task-Goal Attribute n Achievement and Supervisory Performance, Organizational Behavior and Human Performance, 13:392-403.

[36]. Treven, S. (2003), International training: the training of managers for assignment abroad, Education+ Training, 45(8/9):550-557.

[37]. Longenecker, C.O. (2007), The training practices of results-oriented leaders, Industrial andCommercial Training, 39(7):361-367.

[38]. Bartel, A.P. (1994), Productivity gains from the implements of employee training programs, Industrial Relations, 33:411-425.

[39]. Katz, H.C., Kochan, T.A. \& Weber, M.R. (1985), Assessing the effects of industrial relations systems and efforts to improve the quality of working life on organizational effectiveness, Academy of Management Journal, 28:509-526.

[40]. Holzer, H.J., Block, R.N., Cheatham, M. \& Knott, J.H. (1993), Are training subsidies for firms effective? The Michign experience, Industrial and Labor Relations Review, 46:625-636.

[41]. Longenecker, C.O. \& Fink, L.S. (2005), Management training: benefits and lost opportunities (part1), Industrial and Commercial Training, 37:25-30.

[42]. Motowidlo, S.J., Borman, W.C. \&Schmit, M.J. (1997), A theory of individual differences in task and contextual performance, Human Performance, 10:71-83

[43]. Borman, W.C. \&Motowidlo, S.J. (1993), Expanding the criterion domain to include elements of contextual performance, in Schmitt, N. and Borman, W.C. (Eds), Personnel Selection in Organizations, Jossey Bass, San Francisco, CA, pp. $71-98$.

[44]. Rotundo, M. \&Sackett, P.R. (2002), The relative importance of task, citizenship, and counterproductive performance to global ratings of performance: a policy-capturing approach, Journal of Applied Psychology, 87:66-80.

[45]. Griffin, M.A., Neal, A. \& Parker, S.K. (2007), A new model of work role performance: positive behavior in uncertain and interdependent contexts, Academy of Management Journal, 50(2):327-347.

[46]. Reio, T.G. Jr and Wiswell, A. (2000), "Field investigation of the relationship between adult curiosity, workplace learning, and job performance", Human Resource Development Quarterly, Vol. 11, pp. 1-36.

[47]. Ordonez de Pablos, P. \&Lytras, M.D (2008), Competencies and human resource management: implications for organizational competitive advantage, Journal of KnowledgeManagement,12(6):48-55.

[48]. Collins, A.B. (2007), Human resources: a hidden advantage?,International Journal ofContemporary Hospitality Management, 19(1):78-84.

[49]. Chew, K.H. \&Basu, S. (2005), The effects of culture and HRM practices on firm performance. Empirical evidence from Singapore, International Journal of Manpower,26(6):560-581.

[50]. Khandekar, A. \& Sharma, A. (2005), Managing human resource capabilities for sustainable competitive advantage. An empirical analysis from Indian global organizations, Education + Training, 47(8/9):628-639.

[51]. Arthur, J.B. (1994), Effects of human resource systems on manufacturing performance and turnover, Academy of Management Journal, 37:670-680

[52]. Hoque, K. (1999), Human resource management and performance in UK hotel industry, British Journal of Industrial Relations, 37:419-443.

[53]. Youndt, M.A., Snell, S.A., Dean, J.W. \&Lepak, D.P. (1996), Human resource management, manufacturing strategy, and firm performance, Academy of Management Journal, 39(4):836-866.

[54]. Karami, A., Analoui, F. \&Cusworth, J. (2004), Strategic human resource management and resource-based approach: the evidence from the British manufacturing industry, Management Research, 27(6):50-69.

[55]. Green, K., Medlin, B. \& Whitten, D. (2004), Developing optimism to improve performance: an approach for the manufacturing sector, Industrial Management \& Data Systems, 104 (2):106-114.

[56]. Motowidlo, S.J. \& Van Scotter, J.R. (1994), Evidence that task performance should be distinguished from contextual performance, Journal of Applied Psychology, 78:71-83.

[57]. Dumas, A., \&Hanchane, S. (2010). How does job-training increase firm performance? The case of Morocco. International Journal of Manpower, 31(5): 585-608

[58]. Dillman, D.A. (2000), Mail and internet surveys: The Tailored Design Method, 2nd ed., John Wiley \& Sons, New York, NY. 